The Effect of Organic Fertilizers on the Spelt Yield and the Yield of its Components

Utjecaj organskih gnojiva na prinos i komponente prinosa pira

Pospišil, A., Pospišil, M.

Poljoprivreda/Agriculture

ISSN: 1848-8080 (Online)

ISSN: 1330-7142 (Print)

https://doi.org/10.18047/poljo.27.1.5

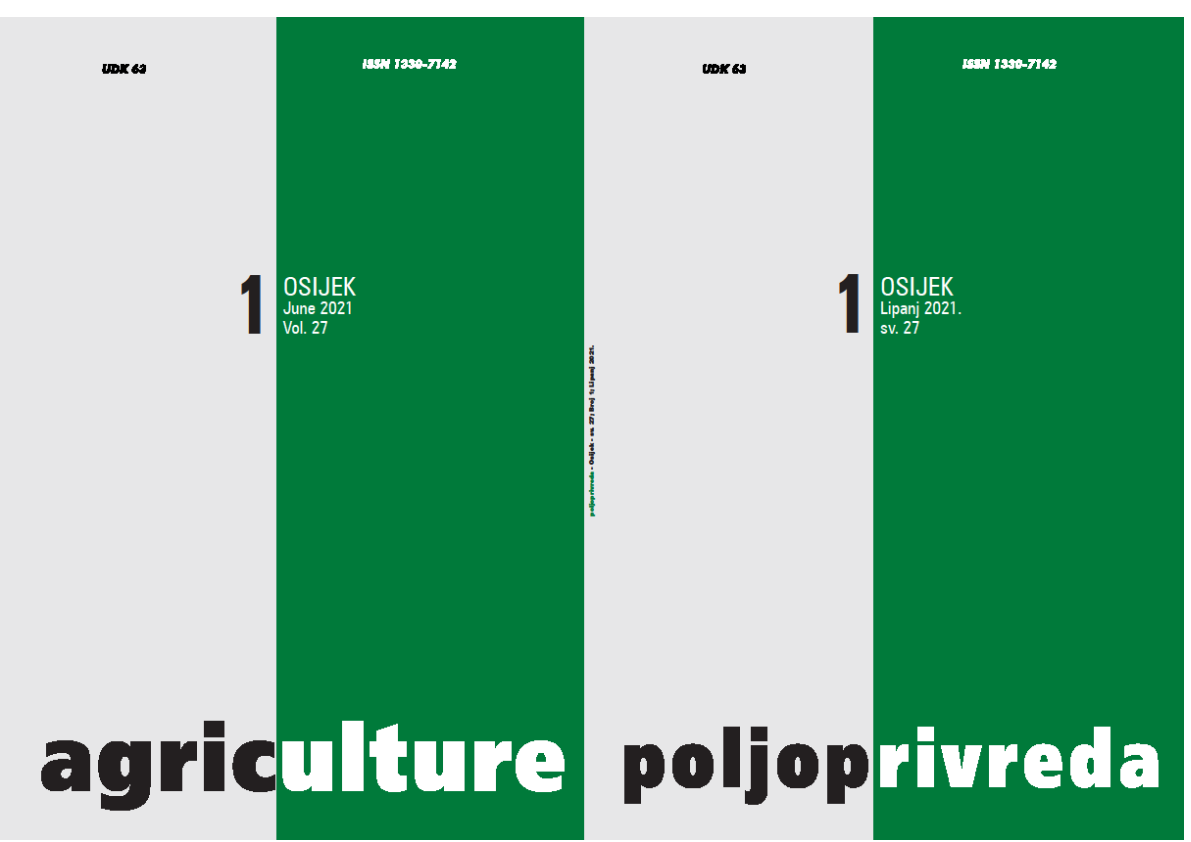

Fakultet agrobiotehničkih znanosti Osijek, Poljoprivredni institut Osijek

Faculty of Agrobiotechnical Sciences Osijek, Agricultural Institute Osijek 


\title{
THE EFFECT OF ORGANIC FERTILIZERS ON THE SPELT YIELD AND THE YIELD OF ITS COMPONENTS
}

\author{
Pospišil, A., Pospišil, M.
}

Original scientific paper

Izvorni znanstveni članak

\begin{abstract}
SUMMARY
The aim of this study was to determine the effect of fertilization with organic fertilizers Fertil Supernova and Ilsamin N90 on the yield and yield components of three spelt varieties. The study was conducted on an anthropogenized eutric cambisol at the experimental site of the Faculty of Agriculture in Zagreb during 2015/16, 2016/17, and 2017/18, respectively. The study included three varieties of spelt, Nirvana, Ostro, and Bc Vigor, as well as a topdressing with organic fertilizers and a control (without topdressing). The first topdressing at the beginning of spring vegetation consisted of the application of organic fertilizer Fertil Supernova in the amount of $300 \mathrm{~kg} \mathrm{ha}^{-1}$, while the second topdressing at the end of tillering consisted of a foliar application of Ilsamin N90 in the amount of 3 I ha-1. The spelt yield and its yield components were significantly influenced by weather conditions, primarily by the amount and distribution of precipitation. The studied spelt varieties did not significantly differ in the grain yield. In all three research years, the variety Nirvana has achieved the significantly largest number of ears per $\mathbf{m}^{2}$. Topdressing with organic fertilizers had a positive impact on the yield of the hulled spelt grain only in the dry year of 2016/17. Topdressing with organic fertilizers did not have a significant impact on the yield components.
\end{abstract}

Keywords: spelt, topdressing, organic fertilizers, yield, yield components, weather conditions

\section{INTRODUCTION}

Spelt (Triticum spelta L.) is an underrepresented cereal in the Republic of Croatia and the European Union. For the last five years, according to the Paying Agency for Agriculture, Fisheries, and Rural Development, spelt in Republic of Croatia has been averagely grown on 2251 ha. By the introduction of spelt into production, the crop rotation is expanded, while biodiversity is increased, which contributes to a sustainable agricultural production. The grain of spelt is wrapped with glumes and should be dehulled before use. The grain has a high protein content, a favorable mineral composition, and a specific taste (Bojňanská and Frančáková, 2002; Kohajdová and Karovičová, 2008; Moudrý et al., 2011). In recent years, spelt flour has been increasingly used for the preparation of bread, biscuits, pasta, etc. Due to its adaptability, spelt is suitable for the cultivation at higher altitudes in poorer agroecological conditions, as well as in the organic production (Bonafaccia and Fabjan, 2003;
Moudrý et al., 2011; Pospišil et al., 2016). Relative to the common wheat, spelt has a lower harvest index and a lower $\mathrm{N}$ harvest index, which indicates a lower proportion of assimilates and nitrogen in the grain (Koutroubas et al., 2012). An advantage of spelt over the common wheat stems from its ability to achieve a high protein content with a small amount of fertilizer (Magistrali et al., 2020; Fatholahi et al., 2020). The cultivation of spelt does not require a large amount of nutrients. If the soil contains more than $20 \mathrm{mg}$ of nitrate nitrogen per $100 \mathrm{~g}$ of soil, nitrogen fertilization is not required (Bavec and Bavec, 2006). However, some authors cite a positive impact of nitrogen fertilization on the spelt yield and the qualitative properties of grain (Hury et al., 2016; Knapowski et al., 2016; Budzyński et al., 2018).

Prof. Dr. Ana Pospišil (apospisil@agr.hr), Prof. Dr. Milan Pospišil University of Zagreb, Faculty of Agriculture, Department of Field Crops, Forage, and Grassland, Svetošimunska cesta 25, 10000 Zagreb, Croatia 
In the organic production, the application of organic fertilizers, microbiological mixtures, and bioactivators had a positive effect on the yield of wheat and spelt (Kovačević et al., 2011; Dolijanović et al., 2012; Dolijanović et al., 2013; Kovačević et al., 2014) as well as on the qualitative grain properties (JablonskyteRašče et al., 2012).

Since spelt is mainly grown within an organic production system, the application of organic fertilizers is necessary in order to achieve a high yield and grain quality, especially on the soils characterized by a lower fertility.

Therefore, this study's objective was to determine the impact of fertilization with organic fertilizers Fertil Supernova and Ilsamin N9O on the yield and yield components of three spelt varieties in the organic production system.

\section{MATERIAL AND METHODS}

The trials were carried out at the experimental facility of the Faculty of Agriculture of the University of Zagreb $\left(45^{\circ} 48^{\prime} \mathrm{N}, 16^{\circ} 05^{\prime} \mathrm{E}\right)$ during three growing seasons (2015/16, 2016/17, and 2017/18, respectively). The trial included three spelt varieties, Nirvana, Ostro, and $B C$ Vigor, and topdressing with organic fertilizers. A control was grown without topdressing. In the first topdressing at the beginning of spring vegetation at the growth stage BBCH 23 (Witzenberger et al., 1989; Lancashire et al., 1991), $300 \mathrm{~kg} \mathrm{ha}^{-1}$ of organic fertilizer Fertil Supernova $(12.5 \% \mathrm{~N})$ were applied $\left(37.5 \mathrm{~kg} \mathrm{ha}^{-1}\right.$ $\mathrm{N})$. In the second topdressing at the end of tillering (BBCH 26), $3 \mathrm{~L} \mathrm{ha}^{-1}$ of the foliar organic fertilizer Ilsamin N90 were applied ( $\left.270 \mathrm{ml} \mathrm{ha}^{-1} \mathrm{~N}\right)$. Fertil Supernova is an organic nitrogen fertilizer, while Ilsamin N90 is a liquid organic fertilizer containing $9 \%$ of nitrogen. The trial was laid out according to the strip-plot method with four replications. The basic plot size in sowing amounted to 8.4 $\mathrm{m}^{2}$ (10 rows $\times 0.12 \mathrm{~m}$ between the rows $\times 7 \mathrm{~m}$ of row length). Upon emergence, the plot length was shortened by $0.5 \mathrm{~m}$, so the plot size during harvest amounted to 7.8 $\mathrm{m}^{2}$. Rapeseed was the forecrop in the first two years, while fallow was the forecrop in the year 2017/18. A basic fertilization was performed using $400 \mathrm{~kg} \mathrm{ha}^{-1}$ of organic fertilizer PROECO 5:10:10 (20 kg ha- ${ }^{-1}, 40 \mathrm{~kg}$ ha $^{-1} \mathrm{P}_{2} \mathrm{O}_{5}$ and $40 \mathrm{~kg} \mathrm{ha}^{-1} \mathrm{~K}_{2} \mathrm{O}$ ). PROECO 5:10:10 is an organic nitrogen:phosphorus:potassium fertilizer based on the animal and plant proteins. Spelt sowing was performed on 26 October 2015, 14 October 2016, and 5 October 2017, respectively. A sowing rate amounted to 300 germinable grains $\mathrm{m}^{-2}$. Upon emergence, the number of emerged plants per $\mathrm{m}^{2}$ was determined, and the number of ears per $\mathrm{m}^{2}$ was determined prior to the harvest. The harvests were carried out by the Wintersteiger plot harvester on 8 July 2016, 4 July 2017, and 20 July 2018 , respectively. The hulled spelt grain yields were determined subsequent to the harvest, and the yields were adjusted to a $13 \%$ moisture content. Ear samples were taken prior to the harvest (10 ears from each plot), and the following traits were determined: spikelet number per ear, grain number per ear, hulled grain weight per ear and the dehulled grain weight per ear. The dehulled grains' proportion was calculated as a mass ratio of the dehulled and hulled grains. The obtained results were processed by an analysis of variance using the MSTAT-C program (Michigan State University, 1990).

The trials were conducted on an anthropogenic eutric cambisol (Vidaček at al., 1994). The upper soil layer was acidic $(\mathrm{pH}$ in $1 \mathrm{M} \mathrm{KCl}=5.29)$, poorly supplied with humus $(1.6 \%)$, and moderately supplied with nitrogen $(0.09 \%)$. The soil was well supplied with the plant available phosphorus (AL - $\mathrm{P}_{2} \mathrm{O}_{5}=28.4 \mathrm{mg}^{100 \mathrm{~g}^{-1}}$ soil) and potassium ( $A L-K_{2} O=21.0 \mathrm{mg} 100 \mathrm{~g} \mathrm{~g}^{-1}$ soil). A soil reaction was determined according to the HRN ISO 10390:2005, humus content was determined by a bichromatic method according to Tjurin (Škorić, 1982), total nitrogen content was determined according to the HRN ISO 11261:2004, and $\mathrm{P}_{2} \mathrm{O}_{5}$ and $\mathrm{K}_{2} \mathrm{O}$ contents were determined by the Al-method (Egner et al., 1960).

\section{RESULTS AND DISCUSSION}

The research was conducted during three growing seasons with different weather conditions that influenced a success of the application of organic fertilizers in the spelt topdressing (Tables 1 and 2). Weather conditions have a significant impact on the morphological and economic properties of spelt (Glamočlija, 2013; Janković, 2015). During the trial period, the highest hulled spelt grain yield was achieved in the year 2017/18 with the favorable weather conditions, while the lowest yield was achieved in the year 2015/16 (Tables 3, 4 and 5). During 2015/16, the distribution and amount of precipitation till June were generally favorable for the spelt growth and development. Only in April, during the stem elongation, a slightly less precipitation was recorded compared to the long-term average, but this did not exert a negative effect on the formation of yield components per ear. During May, when high water consumption continues (Glamočlija, 2013), the amount of precipitation was $26.1 \mathrm{~mm}$ higher than the long-term average, which had a favorable effect on the spelt growth and development. However, a storm that was followed by the strong winds and rain during June 2016 caused a significant crop lodging, which led to the reduced yields. Since spelt has a high stem, lodging is one of the main production problems regardless of the amount of nitrogen applied (Koutroubas et al., 2012; Sugár et al., 2019). During the trial period, the 2016/17 vegetation year received the least amount of precipitation (Table 2). The highest amount of precipitation, following a regular distribution, fell during the 2017/18 vegetation year, which, alongside a favorable air temperature, resulted in the highest spelt yield for this vegetation year. In all three research years, the mean monthly air temperature during the growing season exceeded the long-term average (Table 1). The largest deviation was in the year $20017 / 18\left(1.6^{\circ} \mathrm{C}\right)$, but it did not have a negative impact on the spelt growth and development due to a higher rainfall. 
Table 1. Mean monthly air temperature $\left({ }^{\circ} \mathrm{C}\right)$ during the 2015/16, 2016/17, and 2017/18 growing seasons and a deviation from the long-term average in Zagreb-Maksimir

Tablica 1. Srednje mjesečne temperature zraka $\left({ }^{0} \mathrm{C}\right)$ tijekom vegetacijskih godina 2015./16., 2016./17. i 2017./18. i odstupanja od višegodišnjega prosjeka za Zagreb-Maksimir

\begin{tabular}{|l|c|c|c|c|c|c|}
\hline \multirow{2}{*}{\begin{tabular}{l} 
Month \\
\cline { 2 - 7 }
\end{tabular}} & $\begin{array}{c}\text { Air temp. } \\
\text { Temp. zraka } \\
\left({ }^{\circ} \mathrm{C}\right)\end{array}$ & $\begin{array}{c}\text { Deviation from average } \\
\text { Odstupanje od prosjeka } \\
\left({ }^{\mathrm{C}} \mathrm{C}\right)\end{array}$ & $\begin{array}{c}\text { Air temp. } \\
\text { Temp. zraka } \\
\left({ }^{\circ} \mathrm{C}\right)\end{array}$ & $\begin{array}{c}\text { Deviation from average } \\
\text { Odstupanje od prosjeka } \\
\left({ }^{\circ} \mathrm{C}\right)\end{array}$ & $\begin{array}{c}\text { Air temp. } \\
\text { Temp. zraka } \\
\left({ }^{\circ} \mathrm{C}\right)\end{array}$ & $\begin{array}{c}\text { Deviation from average } \\
\text { Odstupanje od prosjeka } \\
\left({ }^{\circ} \mathrm{C}\right)\end{array}$ \\
\hline October /listopad & 11.2 & -0.1 & 10.4 & -0.9 & 11.9 & 0.6 \\
\hline November/studeni & 8.2 & 2.4 & 6.8 & 1.0 & 7.3 & 1.5 \\
\hline December/prosinac & 3.2 & 1.6 & -0.4 & -2.0 & 4.0 & 2.4 \\
\hline January/siječanj & 1.3 & 0.8 & -3.2 & -3.7 & 5.2 & 4.7 \\
\hline February/veljača & 6.9 & 4.7 & 5.2 & 3.0 & 0.2 & -2.0 \\
\hline March/ožujak & 8.0 & 1.2 & 10.0 & 3.2 & 5.2 & -1.6 \\
\hline April/travanj & 13.0 & 1.6 & 12.4 & 1.0 & 16.1 & 4.7 \\
\hline May/svibanj & 16.1 & -0.4 & 17.7 & 1.2 & 19.5 & 3.0 \\
\hline June/lipanj & 21.1 & 1.5 & 22.5 & 2.9 & 21.4 & 1.8 \\
\hline July/srpanj & 23.4 & 1.9 & 24.0 & 2.5 & 22.5 & 1.0 \\
\hline Average/prosjek & 11.2 & 1.5 & 10.5 & 0.8 & 11.3 & 1.6 \\
\hline
\end{tabular}

Table 2. Total monthly precipitation (mm) during the 2015/16, 2016/17, and 2017/18 growing seasons and the deviation from the long-term average in Zagreb-Maksimir

Tablica 2. Ukupna količina oborina (mm) tijekom vegetacijskih godina 2015./16., 2016./17. i 2017./18. i odstupanje od višegodišnjega prosjeka za Zagreb-Maksimir

\begin{tabular}{|l|c|c|c|c|c|c|}
\hline \multirow{2}{*}{ Month } & \multicolumn{2}{|c|}{$\begin{array}{c}2015 / 16 \\
2016 / 17\end{array}$} & \multicolumn{2}{c|}{$2017 / 18$} \\
\cline { 2 - 7 } & $\begin{array}{c}\text { Precipitation } \\
\text { Oborine } \\
(\mathrm{mm})\end{array}$ & $\begin{array}{c}\text { Deviation from average } \\
\text { Odstupanje od prosjeka } \\
(\mathrm{mm})\end{array}$ & $\begin{array}{c}\text { Precipitation } \\
\text { Oborine } \\
(\mathrm{mm})\end{array}$ & $\begin{array}{c}\text { Deviation from average } \\
\text { Odstupanje od prosjeka } \\
(\mathrm{mm})\end{array}$ & $\begin{array}{c}\text { Precipitation } \\
\text { Oborine } \\
\text { (mm) }\end{array}$ & $\begin{array}{c}\text { Deviation from average } \\
\text { Odstupanje od prosjeka } \\
\text { (mm) }\end{array}$ \\
\hline October/listopad & 174.9 & 94.9 & 107.9 & 27.9 & 72.0 & -8.0 \\
\hline November/studeni & 39.1 & -36.9 & 96.2 & 20.2 & 113.2 & 37.2 \\
\hline December/prosinac & 0.7 & -62.0 & 1.9 & -60.8 & 92.3 & 29.6 \\
\hline January/siječanj & 60.5 & 15.0 & 34.3 & -11.2 & 56.7 & 11.2 \\
\hline February/veljača & 126.8 & 87.2 & 41.4 & 1.8 & 87.5 & 47.9 \\
\hline March/ožujak & 54.3 & 0.2 & 19.8 & -34.3 & 72.2 & 18.1 \\
\hline April/travanj & 49.5 & -10.0 & 44.3 & -15.2 & 65.8 & 6.3 \\
\hline May/svibanj & 94.7 & 26.1 & 35.2 & -33.4 & 68.7 & 0.1 \\
\hline June/lipanj & 130.5 & 33.1 & 107.8 & 10.4 & 127.8 & 30.4 \\
\hline July/srpanj & 46.8 & -24.6 & 58.0 & -13.4 & 85.2 & 13.8 \\
\hline Total/ukupno & 777.8 & 123.0 & 546.8 & -108.0 & 841.4 & 186.6 \\
\hline
\end{tabular}

No significant differences in grain yield were found among the studied spelt varieties in any of the years. In all three research years, the variety Nirvana achieved the significantly highest number of ears per $\mathrm{m}^{2}$ (Tables 3,4 , and 5 ). The studied varieties did not significantly differ in the number of spikelets per spike. Depending on the research year, the number of spikelets per spike ranged from 18.4 to 20.7. In all three research years, the variety Nirvana achieved the highest number of grains per ear, but the difference was statistically significant only in the 2017/18 vegetation year. No significant difference in the mass of dehulled grains per ear was found among the studied varieties. In all three research years, the variety Nirvana achieved the highest proportion of dehulled grains, which ranged from $69.6 \%$ in the year
$2016 / 17$ to $71.7 \%$ in the year $2017 / 18$. Depending on a study year, a content of the dehulled grains in the Ostro variety ranged from 64.7 to $66.7 \%$, while it ranged from 64.3 to $67.6 \%$ in the $B c$ Vigor variety (Tables 3, 4, and 5). The similar results were obtained by Lacko-Bartošová et al. (2010) and Dorval et al. (2015).

Kovacevic et al. (2014) and Korkhova (2019) mention a different reaction of spelt cultivars to the agroecological conditions and indicate an importance of genotype selection according to the environmental conditions.

Topdressing with organic fertilizers Fertil Supernova and IIsamin N9O has significantly increased the hulled spelt grain yield only in the dry year of 2016/17 (Table 
4). Other researchers have found a positive effect of nitrogen fertilization on the reduction of drought caused stress (Feiziasl et al., 2014; Sedri et al., 2019) and foliar nitrogen fertilization in the conditions when the drought limits a nitrogen uptake from the soil (Kovačević and Rastija, 2014; Ahmad et al., 2014).

Topdressing with organic fertilizers did not significantly affect the number of ears per $\mathrm{m}^{2}$ or other yield components. Andruszczak et al. (2011) state a positive effect of mineral fertilizers on the spelt grain yield and the number of ears, not affecting the number and grain weight per ear and the wight of 1,000 grains. Budzyński et al. (2018) cite a positive effect of nitrogen fertilizer application on the spelt yield during the spring vegetation part. However, the application of nitrogen did not affect the number of grains per ear or the weight of 1,000 grains. Other researchers also report a positive effect of fertilization with organic fertilizers on the spelt yield, alongside the application of microbiological fertilizers and bioactivators during vegetation (Dolijanović et al., 2012; Jablonskytè-Raščè et al., 2012). However, the studies by Krochmal-Marczak and Sawicka (2011), Glamočlija et al. (2013), and Magistrali et al. (2020) indicate the adaptability of spelt to the conditions of lower soil fertility and lower nitrogen fertilization, whereas Sugár et al. (2019) recommend spelt as an alternative to the cultivation of wheat in such conditions.

Table 3. The effect of organic fertilizer topdressing on the spelt yield and the yield of its components during the 2015/16 vegetation year

Tablica 3. Utjecaj prihrane organskim gnojivima na prinos $i$ komponente prinosa istraživanih sorata pira u vegetacijskoj godini 2015./16.

\begin{tabular}{|c|c|c|c|c|c|c|c|}
\hline $\begin{array}{l}\text { Variety } \\
\text { Sorta }\end{array}$ & $\begin{array}{c}\text { Topdressing } \\
\text { Prihrana } \\
\end{array}$ & $\begin{array}{l}\text { Hulled grain yield } \\
\text { Prinos neoljušteno- } \\
\text { ga zrna }\left(\mathrm{kg} \mathrm{ha}^{-1}\right)\end{array}$ & $\begin{array}{c}\text { Ear number per } \mathrm{m}^{2} \\
\text { Broj klasova } \\
\text { po } \mathrm{m}^{2} \\
\end{array}$ & $\begin{array}{l}\text { Spikelet num- } \\
\text { ber per ear } \\
\text { Broj klasića } \\
\text { po klasu }\end{array}$ & $\begin{array}{c}\text { Grain num- } \\
\text { ber per ear } \\
\text { Broj zrna po } \\
\text { klasu } \\
\end{array}$ & $\begin{array}{c}\text { Dehulled grain weight } \\
\text { per ear } \\
\text { Masa oljuštenih zrna } \\
\text { po klasu }(\mathrm{g})\end{array}$ & $\begin{array}{c}\text { Dehulled grain } \\
\text { content } \\
\text { Udio oljuštenih } \\
\text { zrna (\%) } \\
\end{array}$ \\
\hline \multirow[t]{2}{*}{ Nirvana } & C & 3433 & 430 & 20.5 & $33.6 \mathrm{a}$ & $1.37 \mathrm{a}$ & 71.9 \\
\hline & $\mathrm{T}$ & 3842 & 417 & 20.3 & $27.7 \mathrm{~b}$ & $1.07 \mathrm{~b}$ & 70.4 \\
\hline \multirow[t]{2}{*}{ Ostro } & C & 3308 & 358 & 20.2 & $23.2 \mathrm{c}$ & $1.10 \mathrm{~b}$ & 67.3 \\
\hline & $T$ & 3610 & 352 & 20.6 & $24.3 \mathrm{c}$ & $1.11 \mathrm{~b}$ & 66.0 \\
\hline \multirow{2}{*}{ Bc Vigor } & C & 3579 & 399 & 20.6 & $24.1 \mathrm{c}$ & $1.13 b$ & 69.4 \\
\hline & $\mathrm{T}$ & 3736 & 376 & 20.7 & $24.3 \mathrm{c}$ & $1.10 \mathrm{~b}$ & 65.7 \\
\hline \multirow{3}{*}{$\begin{array}{l}\text { Mean/prosjek } \\
\text { Variety/sorta }\end{array}$} & Nirvana & 3637 & $423 \mathrm{a}$ & 20.4 & 30.7 & 1.22 & $71.1 \mathrm{a}$ \\
\hline & Ostro & 3459 & $356 \mathrm{~b}$ & 20.4 & 23.8 & 1.11 & $66.7 \mathrm{~b}$ \\
\hline & Bc Vigor & 3658 & $388 a b$ & 20.7 & 24.2 & 1.11 & $67.6 \mathrm{~b}$ \\
\hline \multirow{2}{*}{$\begin{array}{l}\text { Mean/prosjek } \\
\text { Topdressing } \\
\text { Prihrana }\end{array}$} & C & 3440 & 396 & 20.4 & 26.9 & 1.20 & 69.5 \\
\hline & $\mathrm{T}$ & 3429 & 382 & 20.6 & 25.5 & 1.09 & 67.4 \\
\hline
\end{tabular}

$\mathrm{C}$ - control without topdressing, T- topdressing. The values followed by the same letter are not significantly different at a $5 \%$ probability level

Table 4. The effect of organic fertilizer topdressing on the spelt yield and the yield of its components during the 2016/17 vegetation year

Tablica 4. Utjecaj prihrane organskim gnojivima na prinos i komponente prinosa istraživanih sorata pira u vegetacijskoj godini 2016./17.

\begin{tabular}{|c|c|c|c|c|c|c|c|}
\hline $\begin{array}{l}\text { Variety } \\
\text { Sorta }\end{array}$ & $\begin{array}{c}\text { Topdressing } \\
\text { Prihrana }\end{array}$ & $\begin{array}{l}\text { Hulled grain yield } \\
\text { Prinos neoljušteno- } \\
\text { ga zrna (kg ha-1) }\end{array}$ & $\begin{array}{c}\text { Ear number } \\
\text { per } \mathrm{m}^{2} \\
\text { Broj klasova } \\
\text { po } \mathrm{m}^{2}\end{array}$ & $\begin{array}{c}\text { Spikelet num- } \\
\text { ber per ear } \\
\text { Broj klasića } \\
\text { po klasu }\end{array}$ & $\begin{array}{c}\text { Grain number } \\
\text { per ear } \\
\text { Broj zrna po } \\
\text { klasu }\end{array}$ & $\begin{array}{l}\text { Dehulled grain } \\
\text { weight per ear } \\
\text { Masa oljuštenih } \\
\text { zrna po klasu (g) }\end{array}$ & $\begin{array}{l}\text { Dehulled grain } \\
\text { content } \\
\text { Udio oljuštenih } \\
\text { zrna }(\%)\end{array}$ \\
\hline \multirow[t]{2}{*}{ Nirvana } & C & 3272 & 319 & 18.8 & 25.2 & 1.19 & 69.9 \\
\hline & $\mathrm{T}$ & 4234 & 356 & 18.1 & 24.6 & 1.20 & 69.3 \\
\hline \multirow[t]{2}{*}{ Ostro } & C & 3506 & 252 & 18.9 & 25.7 & 1.42 & 65.4 \\
\hline & $\mathrm{T}$ & 3940 & 295 & 18.2 & 22.4 & 1.19 & 64.0 \\
\hline \multirow{2}{*}{ Bc Vigor } & C & 3521 & 297 & 18.9 & 23.8 & 1.27 & 64.0 \\
\hline & $\mathrm{T}$ & 4043 & 303 & 18.7 & 22.4 & 1.18 & 64.7 \\
\hline \multirow{3}{*}{$\begin{array}{l}\text { Mean/prosjek } \\
\text { Variety/sorta }\end{array}$} & Nirvana & 3753 & 337 a & 18.4 & 24.9 & 1.20 & $69.6 \mathrm{a}$ \\
\hline & Ostro & 3723 & $273 \mathrm{~b}$ & 18.6 & 24.1 & 1.31 & $64.7 \mathrm{~b}$ \\
\hline & Bc Vigor & 3782 & $300 \mathrm{~b}$ & 18.8 & 23.1 & 1.23 & $64.3 \mathrm{~b}$ \\
\hline \multirow{2}{*}{$\begin{array}{l}\text { Mean/prosjek } \\
\text { Topdressing } \\
\text { Prihrana }\end{array}$} & C & $3433 \mathrm{~b}$ & 289 & 18.9 & 24.9 & 1.29 & 66.4 \\
\hline & $\mathrm{T}$ & $4072 \mathrm{a}$ & 318 & 18.3 & 23.1 & 1.19 & 66.0 \\
\hline
\end{tabular}

C - control without topdressing, T- topdressing. The values followed by the same letter are not significantly different at a $5 \%$ probability level 
Table 5. The effect of organic fertilizer topdressing on the spelt yield and the yield of its components during the 2017/18 vegetation year

Tablica 5. Utjecaj prihrane organskim gnojivima na prinos i komponente prinosa istraživanih sorata pira u vegetacijskoj godini 2017./18.

\begin{tabular}{|c|c|c|c|c|c|c|c|}
\hline $\begin{array}{l}\text { Variety } \\
\text { Sorta }\end{array}$ & $\begin{array}{c}\text { Topdressing } \\
\text { Prihrana }\end{array}$ & $\begin{array}{c}\text { Hulled grain yield } \\
\text { Prinos neoljušte- } \\
\text { noga zrna (kg } \\
\text { ha }^{-1} \text { ) }\end{array}$ & $\begin{array}{l}\text { Ear number per } \\
\mathrm{m}^{2} \\
\text { Broj klasova } \\
\text { po } \mathrm{m}^{2}\end{array}$ & $\begin{array}{l}\text { Spiklet number } \\
\text { per ear } \\
\text { Broj klasića po } \\
\text { klasu }\end{array}$ & $\begin{array}{l}\text { Grain number } \\
\text { per ear } \\
\text { Broj zrna po } \\
\text { klasu }\end{array}$ & $\begin{array}{l}\text { Dehulled grain } \\
\text { weight per ear } \\
\text { Masa oljuštenih } \\
\text { zrna po klasu }(\mathrm{g})\end{array}$ & $\begin{array}{l}\text { Dehulled grain } \\
\text { content } \\
\text { Udio oljuštenih } \\
\text { zrna (\%) }\end{array}$ \\
\hline \multirow[t]{2}{*}{ Nirvana } & C & 3840 & 382 & 19.7 & 25.2 & 1.09 & 71.0 \\
\hline & $\mathrm{T}$ & 4482 & 381 & 19.8 & 27.8 & 1.31 & 72.4 \\
\hline \multirow[t]{2}{*}{ Ostro } & C & 3738 & 338 & 19.4 & 22.7 & 1.07 & 65.3 \\
\hline & $\mathrm{T}$ & 4210 & 340 & 19.6 & 23.2 & 1.11 & 64.3 \\
\hline \multirow[t]{2}{*}{ Bc Vigor } & $C$ & 3817 & 322 & 19.4 & 23.5 & 1.09 & 65.6 \\
\hline & $\mathrm{T}$ & 4495 & 370 & 19.4 & 23.9 & 1.12 & 63.9 \\
\hline \multirow{3}{*}{$\begin{array}{l}\text { Mean/prosjek } \\
\text { Variety/sorta }\end{array}$} & Nirvana & 4161 & 381 a & 19.7 & 26.5 a & 1.20 & 71.7 a \\
\hline & Ostro & 3974 & $339 \mathrm{~b}$ & 19.5 & $23.0 \mathrm{~b}$ & 1.09 & $64.8 \mathrm{~b}$ \\
\hline & Bc Vigor & 4156 & $346 \mathrm{~b}$ & 19.4 & $23.7 \mathrm{~b}$ & 1.11 & $64.8 \mathrm{~b}$ \\
\hline \multirow{2}{*}{$\begin{array}{l}\text { Mean/prosjek } \\
\text { Topdressing } \\
\text { Prihrana }\end{array}$} & C & 3798 & 347 & 19.5 & 23.8 & 1.08 & 67.3 \\
\hline & $\mathrm{T}$ & 4396 & 364 & 19.6 & 24.9 & 1.18 & 66.9 \\
\hline
\end{tabular}

$\mathrm{C}$ - control without topdressing, $\mathrm{T}$ - topdressing. The values followed by the same letter are not significantly different at a $5 \%$ probability level

\section{CONCLUSION}

Based on the three-year study results of the influence of fertilization with organic fertilizers on the spelt yield and the yield of its components, the following conclusions can be made:

- the yield of the hulled spelt grain significantly depended on the year of research, primarily on the amount and distribution of precipitation

- the studied varieties did not significantly differ in the yield of the hulled grain

- in all three research years, the variety Nirvana has achieved the significantly largest number of ears per $\mathrm{m}^{2}$.

Topdressing with organic fertilizers Fertil Supernova and IIsamin N9O had a positive effect on the yield of hulled spelt grain only in the dry year 2016/2017, while in the other two years the influence of weather conditions prevailed. Topdressing with organic fertilizers did not have a significant impact on the spelt yield components.

\section{REFERENCES}

1. Ahmad, R., Waraich, E. A., Ashraf, M. Y., Ahmad, S., \& Aziz, T. (2014). Does nitrogen fertilization enhance drought tolerance in sunflower? A review. Journal of Plant Nutrition, 37(6), 942-963.

https://doi.org/10.1080/01904167.2013.868480

2. Andruszczak, S., Kwiecińska-Poppe, E., Kraska, P., \& Pałys, E. (2011). Yield of winter cultivars of spelt wheat (Triticum aestivum ssp. spelta L.) cultivated under divesified conditions of mineral fertilization and chemical protection. Acta Scientiarum Polonorum series Agricultura 10(4), 5-14.

3. Bavec, F., Bavec, M. (2006). Organic production and use of alternative crops, Taylor \& Francis Group.
4. Bojňanská, T., \& Frančáková, H. (2002). The use of spelt wheat (Triticum spelta L.) for baking applications. Rostlinná Výroba, 48(4), 141-147. https://doi.org/10.17221/4212-PSE

5. Budzyński, W. S., Bepirszcz, K., Jankowski, K. J., Dubis, B., Hłasko-Nasalska, A., Sokólski, M. M., ... \& Załuski, D. (2018). The responses of winter cultivars of common wheat, durum wheat and spelt to agronomic factors. The Journal of Agricultural Science, 156(10), 1163-1174. https://doi.org/10.1017/S0021859619000054

6. Bonafaccia, G., \& Fabjan, N. (2003). Nutritional comparison of tartary buckwheat with common buckwheat and minor cereals. Zb. Bioteh. Fak. Univ. Ljublj. Kmet. 8 1-2, oktober 2003, 349-355.

7. Dolijanović, Ž., Oljača, S., Kovačević, D., Jug, I., Stipešević, B., \& Poštić, D. (2012). Utjecaj agrotehničkih mjera na prinos zrna pira (Triticum aestivum spp. spelta) u organskom sustavu uzgoja. Proceedings 47th Croatian \& 7th International Symposium on Agriculture, Opatija, February 13 - 17, 2011, p. 51-55.

8. Dolijanovic, Z., Oljaca, S., Kovacevic, D., Đorđević, S., \& Brdar, J. (2013). The effects of different fertilizers on spelt grain yield (Triticum aestivum ssp. spelta). Book of proceedings IV International Symposium "Agrosym 2013", Jahorina, October 3-6, 2013, p. 506-510.

9. Dorval, I., Vanasse, A., Pageau, D., \& Dion, Y. (2015). Seeding rate and cultivar effects on yield, yield components and grain quality of spring spelt in eastern Canada. Canadian Journal of Plant Science, 95(5), 841-849. https://doi.org/10.4141/cjps-2014-439

10. Egnér, H. A. N. S., Riehm, H., \& Domingo, W. R. (1960). Untersuchungen über die chemische Bodenanalyse als Grundlage für die Beurteilung des Nährstoffzustandes der Böden. II. Chemische Extraktionsmethoden zur Phosphorund Kaliumbestimmung. Kungliga Lantbrukshögskolans Annaler, 26, 199-215.

11. Fatholahi, S., Ehsanzadeh, P., \& Karimmojeni, H. (2020). Ancient and improved wheats are discrepant in nitrogen 
uptake, remobilization, and use efficiency yet comparable in nitrogen assimilating enzymes capabilities. Field Crops Research, 249, 107761.

https://doi.org/10.1016/j.fcr.2020.107761

12. Feiziasl, V., Fotovat, A., Astarae, A. R., Lakzian, A., \& Mousavi, S. B. (2014). Effect of optimized nitrogen application in reducing drought stress effect on grain yield of some rainfed bread wheat genotypes. Seed and Plant Production Journal, 30(2), 169-198.

13. Glamočlija, Đ., Janković, S., Popović, V., Ugrenović, V., Zekić, N., Ikanović, J., \& Rakić, S. (2013). Morphological and production characteristics of spelt wheat on the chernozem and degraded soil. Book of Proceedings IV International Scientific Symposium "Agrosym 2013, Jahorina, October 3-6, 2013, 364-369.

14. HRN ISO 10390:2005, Soil quality, Determination of $\mathrm{pH}$ (ISO 10390:2005)

15. HRN ISO 11261:2004, Soil quality, Determination of total nitrogen, Modified Kjeldahl

16. Hury, G., Stankowski, S., Makarewicz, A., Sabolewska, M., Biel, W., \& Opatowicz, N. (2016). The effect of soil tillage system and nitrogen fertilization on baking quality of winter spelt cultivars. Folia Pomeranae Universitatis Technologiae Stetinensis Agricultura Alimentaria Piscaria et Zootechnica, 330(40), 91-100. https://doi.org/10.21005/AAPZ2016.40.4.10

17. Jablonskytė-Raščè, D., Maikštènienè, S., Cesevičienè, J., \& Mankevičienè, A. (2012). Effect of ecologic fertilizers and bio-activators on productivity and yield quality of common (Triticum aestivum L.) and spelt (Triticum spelta L.) wheat. Žemés ūkio mokslai, 19(1), 1-10.

18. Jankovic, S., Ikanovic, J., Popovic, V., Rakic, S., Pavlovic, S., Ugrenovic, V., ... \& Doncic, D. (2015). Morphological and productive traits of spelt wheat - Triticum spelta L. Agriculture \& Forestry, 61(2), 173-182. https://doi.org/10.17707/AgricultForest.61.2.15

19. Knapowski, T., Kozera, W., Chmielewski, J., Gorczyca, D., Wszelaczyńska, E., \& Pobereżny, J. (2016). Mineral fertilization as a factor determining technological value of grain of Triticum aestivum ssp. spelta L. Environmental Protection and Natural Resources, 27(3), 8-13. https://doi.org/10.1515/oszn-2016-0021

20. Kohajdová, Z., \& Karovicová, J. (2008). Nutritional value and baking applications of spelt wheat. Acta Scientiarum Polonorum, Technologia Alimentaria, 7(3), 5-14.

21. Korkhova, M. (2019). Productivity of winter wheat spelt in the South Steps of Ukraine. Ukrainian Black Sea Region Agrarian Science, 104(4), 30-37. https://doi.org/10.31521/2313-092X/2019-4(104)-4

22. Koutroubas, S. D., Fotiadis, S., \& Damalas, C. A. (2012). Biomass and nitrogen accumulation and translocation in spelt (Triticum spelta) grown in a Mediterranean area. Field Crops Research, 127, 1-8.

https://doi.org/10.1016/j.fcr.2011.10.011

23. Kovačević, D., Oljača, S., \& Dolijanović, Ž. (2011). Grain yields of alternative small grains in organic field production. Proceedings 46th Croatian \& 6th International Symposium on Agriculture, Opatija, February 14 - 18, 2011. p. $80-83$.

24. Kovačević, D., Roljević, S., Dolijanović, Ž., Djordjević, S., \& Milić, V. (2014). Different genotypes of alternative small grains in organic farming. Genetika, 46/1), 169 178. https://doi.org/10.2298/GENSR1401169K

25. Kovačević, V., \& Rastija, M. (2014). Žitarice. Sveučilište Josipa Jurja Strossmayera u Osijeku, Poljoprivredni fakultet, Osijek.

26. Krochmal-Marczak, B., \& Sawicka, B. (2011). The influence of climatic and soil conditions on spelt (Triticum aestivum ssp. spelta) cultivated in the Podkarpackie region. Proceedings of International Conference "Protection of agricultural soils against joint stress of natural and anthropogenic factors" $13^{\text {th }}-16^{\text {th }}$ June 2011, Puławy, $p$. 127-128.

27. Lacko-Bartošová, M., Korczyk-Szabó, J., \& Ražný, R. (2010). Triticum spelta - a speciality grain for ecological farming systems. Research Journal of Agricultural Science, 42(1), 143-147.

28. Lancashire, P. D., Bleiholder, H., Van den Boom, T., Langelüddeke, P., Stauss, R., Weber, E., \& Witzenberger, A. (1991). A uniform decimal code for growth stages of crops and weeds. Annals of Applied Biology, 119(3), 561-601. https://doi.org/10.1111/j.1744-7348.1991.tb04895.x

29. Magistrali, A., Vavera, R., Janovska, D., Rempelos, L., Cakmak, I., Leifert, C., ... \& Bilsborrow, P. (2020) Evaluating the effect of agronomic management practices on the performance of differing spelt (Triticum spelta) cultivars in contrasting environments. Field Crops Research, 255, 107869. https://doi.org/10.1016/j.fcr.2020.107869

30. Moudrý, J., Konvalina, P., Stehno, Z., Capouchová, I., \& Moudrý, J. Jr. (2011). Ancient wheat species can extend biodiversity of cultivated crops. Scientific Research and Essays, 6(20), 4273-4280.

https://doi.org/10.5897/SRE11.928

31. MSTAT-C, Michigan State University, 1990.

32. Paying Agency for Agriculture, Fisheries and Rural Development (https://www.apprrr.hr/, accessed $2^{\text {nd }}$ April 2021)

33. Pospišil, A., Pospišil, M., \& Brčić, M. (2016). Influence of seeding rate and nitrogen topdressing upon the agronomic traits of spelt (Triticum spelta L.). Romanian Agricultural Research, 33, 235-240.

34. Sedri, M. H., Amini, A., \& Golchin, A. (2019). Evaluation of nitrogen effects on yield and drought tolerance of rainfed wheat using drought stress indices. Journal of Crop Science and Biotechnology, 22(3), 235-242.

35. Sugár, E., Fodor, N., Sándor, R., Bónis, P., Vida, G., \& Árendás, T. (2019). Spelt Wheat: An Alternative for Sustainable Plant Production at Low N-Levels. Sustainability, 11(23), 6726 . https://doi.org/10.3390/su11236726

36. Škorić, A. (1982). Priručnik za pedološka istraživanja. Fakultet poljoprivrednih znanosti, Zagreb.

37. Vidaček, Ž., Sraka, M., Husnjak, S., \& Pospišil, M. (1994). Lizimetrijsko mjerenje otjecanja vode iz tla u uvjetima agroekološke postaje Zagreb-Maksimir. Znanstveni skup "Poljoprivreda i gospodarenje vodama", Bizovačke Toplice, 17.-19. studenog 1994. godine, Priopćenja: 223-232.

38. Witzenberger, A., Van den Boom, T., \& Hack, H. (1989). Erläuterungen zum BBCH Dezimal-Code für die Entwicklungsstadien des Getreides - mit Abbildungen. Gesunde Pflanzen, 41(11), 384-388. 


\section{UTJECAJ ORGANSKIH GNOJIVA NA PRINOS I KOMPONENTE PRINOSA PIRA}

\section{SAŽETAK}

Cilj istraživanja bio je uturditi utjecaj prihrane organskim gnojivima Fertil Supernova $i$ llsamin N90 na prinos i komponente prinosa triju sorata pira. Istraživanja su provedena na antropogeniziranome eutrično smeđem tlu na pokušalištu Agronomskoga fakulteta u Zagrebu tijekom 2015./16., 2016./17. i 2017./18. godine. U istraživanju su bile tri sorte pira: Nirvana, Ostro $i$ Bc Vigor te prihrana organskim gnojivima $i$ kontrola (bez prihrane). U prvoj prihrani na početku proljetne vegetacije primijenjeno je organsko gnojivo Fertil Supernova u količini od $300 \mathrm{~kg} \mathrm{ha}^{-1}$, a u drugoj prihrani na kraju busanja folijarno je primijenjen Ilsamin N90 u dozi od 3 I ha-1. Na prinos $i$ komponente prinosa pira značajno su utjecale vremenske prilike, prvenstveno količina $i$ raspored oborina. Istraživane sorte nisu se značajno razlikovale u prinosu zrna. U sve tri godine istraživanja sorta Nirvana ostvarila je značajno najveći broj klasova po $\mathbf{m}^{2}$. Prihrana organskim gnojivima imala je pozitivan utjecaj na prinos neoljuštenoga zrna pira samo u sušnoj 2016./17. godini. Prihrana organskim gnojivima nije imala značajan utjecaj na komponente prinosa.

Ključne riječi: pir, prihrana, organska gnojiva, prinos, komponente prinosa, vremenske prilike

(Received on February 9, 2021; accepted on April 9, 2021 - Primljeno 9. veljače 2021.; prihvaćeno 9. travnja 2021.) 